\title{
APPLICATION OF THE TOPSIS PROCEDURE FOR EVALUATION OF SOCIO-ECONOMIC DEVELOPMENT OF THE WEST POMERANIAN VOIVODESHIP DISTRICTS IN YEARS 2004-2017
}

\author{
ZASTOSOWANIE PROCEDURY TOPSIS DO OCENY \\ ROZWOJU SPOŁECZNO-GOSPODARCZEGO POWIATÓW \\ WOJEWÓDZTWA ZACHODNIOPOMORSKIEGO W LATACH 2004-2017
}

https://doi.org/10.34739/zn.2019.49.09

\author{
Maciej Oesterreich ${ }^{1}$, Joanna Perzyńska², Emilia Barej-Kaczmarek ${ }^{3}$ \\ ${ }^{1}$ Poland, West Pomeranian University of Technology Szczecin, Faculty of Economics \\ Department of Mathematical Applications in Economy \\ ORCID: 0000-0003-4750-3636, e-mail: moesterreich@zut.edu.pl \\ 2 Poland, West Pomeranian University of Technology Szczecin, Faculty of Economics \\ Department of Mathematical Applications in Economy \\ ORCID: 0000-0002-7182-2381, e-mail: jperzynska@zut.edu.pl \\ ${ }^{3}$ Poland, West Pomeranian University of Technology Szczecin, Faculty of Economics \\ Department of System Analysis and Marketing \\ ORCID: 0000-0001-5230-7205, e-mail: ebarej@zut.edu.pl
}

\begin{abstract}
The article presents the problem of local socio-economic development. An illustration of theoretical considerations is an empirical study on evaluation of the West Pomeranian Voivodship districts' development since Poland's accession to the European Union. In the research, a taxonomic measure of development was used to assess the level and rate of districts' development. The empirical study was carried out in four main stages: collection of initial characteristics, reduction of the initial set of diagnostic features (to ensure their highest diagnostic value), calculations of synthetic measures using the modified TOPSIS procedure and construction of rankings of districts on that basis, creation of typological groups of districts characterized by a similar level and the pace of development. The study showed the existence of large diversification of economic development of the surveyed districts. The highest level of socio-economic development in both: 2004 and 2017 was characteristic for the Kamieński district and the lowest level of development in 2004 was observed in the Wałecki district and in 2017 in the Gryficki district. The highest pace of changes in the level of socio-economic development between 2004 and 2017 was recorded for the Białogardzki district, while the lowest for the Świdwiński district.

Keywords: district, local socio-economic development, taxonomic measure of development, TOPSIS procedure, West Pomeranian Voivodship

Streszczenie: Artykuł przedstawia zagadnienie lokalnego rozwoju społeczno-gospodarczego. Ilustracją rozważań teoretycznych jest badanie empiryczne dotyczące oceny rozwoju powiatów województwa zachodniopomorskiego od czasu wstąpienia Polski do Unii Europejskiej. W przeprowadzonym badaniu do oceny poziomu i tempa rozwoju powiatów zastosowano taksonomiczny miernik rozwoju. Badanie empiryczne przebiegało w czterech głównych etapach: zebranie cech, redukcja początkowego zbioru cech (dla zapewnienia ich jak największej wartości diagnostycznej), wyznaczenie mierników syntetycznych za pomocą zmodyfikowanej procedury TOPSIS i skonstruowanie na ich podstawie rankingów powiatów, utworzenie grup typologicznych powiatów charakteryzujących się podobnym poziomem i tempem rozwoju. Przeprowadzone badanie wykazało występowanie dużego zróżnicowania rozwoju ekonomicznego badanych powiatów. Najwyższy poziom rozwoju dla obu okresów odnotowano dla powiatu kamieńskiego, zaś najniższy w 2004 dla wałeckiego i w 2017 dla gryfickiego. Najwyższym tempem zmian poziomu rozwoju społeczno-gospodarczego charakteryzował się powiat białogardzki, natomiast najniższym świdwiński.
\end{abstract}

Słowa kluczowe: powiat, lokalny rozwój społeczno-gospodarczy, taksonomiczny miernik rozwoju, procedura TOPSIS, województwo zachodniopomorskie 


\section{Introduction}

Socio-economic development is conditioned historically, spatially and geographically. Its level is influenced by many factors, both those whose entity has an influence on and is independent of. It covers not only economic changes, but also cultural, political and social ones. The development category is multidimensional and results from the number of factors that shape it. Because of its complicated nature, the subject of research is, among others, economics and economic policy. In the assessment of the level of the objects' development it is possible to apply statistical methods. In ordering and classifying objects, aggregate measures can be used - synthetic measures of development, being the result of features describing objects and phenomena.

The article focuses on districts and their social and economic development. The analysis was based on: demographic, labour market, environment, recreation and culture, infrastructure and the economy data. The aim of the study was to assess the level and rate of changes in socioeconomic development of the districts of the West Pomeranian Voivodship in 2004-2017, i.e. since Poland's accession to the European Union, and the final year resulted from the availability of statistical material. A modification of the TOPSIS method was used for the assessment, in which a common pattern and anti-pattern were used, to determine the synthetic measure of development (Walesiak and Obrębalski, 2017). During the empirical research, the hypothesis that the levels and rates of change of development of the districts of the West Pomerania Voivodship are diversificated was verified.

\section{Literature review}

The uneven socio-economic situation of local governments is obviously not indifferent to their residents, as well as to their representatives. Local and regional authorities take active action to improve the living conditions of the population and influence regional and local development (Winiarski and Patrzałek, 1994, p. 15). According to Parysek (Parysek, 2002, p. 47; Parysek, 1995, p. 37) local development is a long-term process, controlled and modified by local government, using local factors, take action to achieve specific goals of the economic and social development of the local area using its resources, taking into account the needs of residents and with their participation in the undertaken activities.
Local development is often interpreted as a process that concerns important changes taking place in the local socio-territorial system (Gorynia and Łaźniewska, 2010, p. 157). This system is usually characterized by individual properties of area, economy and culture, as well as a hierarchy of needs and values, specific to a given region. Local development is a complex concept, where the level of this complexity is connected with various strategic goals, which development is primarily to serve, and the variety of activities and undertakings that ultimately shape it (Szewczuk et al., 2011, p. 21; Brol, 1998, p. 10). The objectives (areas) of regional development include (Dasi, 2014, p. 19):

- ensuring the availability of public goods,

- overcoming social and economic inequalities,

- guaranteeing basic citizenship rights.

At the same time, development plans and development strategies have been identified as the main determinants that help regions maximize their potential. On a local scale, the identification of the sphere of social, economic and spatial development becomes particularly complicated because a region functions and develops as an integral part of a larger whole, uses goods and services created in other areas, and at the same time provides its products to the environment and absorbs funds from outside and transfers its own resources to other areas. Local development concerns many dimensions, and the basic ones include (Frączkiewicz-Wronka, 2007, p. 23):

1. socio-cultural dimension: the process of demographic, social and cultural changes;

2. environmental dimension: changes in the natural environment and infrastructure concerning on environmental protection;

3. infrastructure dimension: development of infrastructure systems in various fields, such as: transport, telecommunications, power engineering, water supply, sewage supply, heating;

4. spatial dimension: new forms of spatial development, changes in management, newly developed spaces (areas).

However, the effect of local development is the creation of new values, which are, among others: working places, improvement of social technical infrastructure, improvement of the natural environment, increase the value of investment, etc. (Łaźniewska and Gorynia, 2012, p. 177-178).

In Poland, a strong impulse stimulating the development of the country as a whole (Grycuk and Russel, 2017) and its regions (Gorzelak and 
Smętkowski, 2019) was the accession to the European Union in 2004. Regional development is one of the pillars of this organization and one of the most important assumptions of cohesion policy. As mentioned in the report (European Commission, 2019), a significant impact on the development directions of member states have seventeen "Sustainable Development Goals" (UN, 2015), which are part of the Agenda 2030. These issues include not only the problem of internal development, but also cooperation with neighbouring countries (and regions), also those that are not members of the EU (European Commission, 1999, PLATFORM, 2012).

The document (European Commission, 2014) presents the assumptions of Community-led Local Development (CLLD) which is part of the cohesion policy for 2014-2020. These activities focus on regions and are carried out and supervised by local groups. They must be based on local development strategies (Wiatrak, 2018) and take into account the potential and needs of the local community. The programme assumes multifaceted cooperation of various groups and entities (see Cyburt et al., 2016; OECD, 2018; Sienkiewicz, 2015).

As highlighted in the report of Sheffield Political Economy Research (SPERI, 2018) on the financing of EU regions in the context of Great Britain, the funds stimulate the labour market and economic activity of regions. They enable, among others implementation of projects which financing from general funds would be impossible or difficult. This is also due to the fact that due to the long-term sustainability of financing these sources, local authorities can create more stable investment plans.

\section{Materials and methods}

In empirical research twenty-one districts (including 3 cities with district status) of the West Pomeranian Voivodship were examined. Evaluation of their development proceeded in four main stages.

\section{Stage 1. Collection of initial characteristics}

The data used in the analysis concerned the years 2004 and 2017 and came (or were calculated) from the publication of the Central Statistical Office (GUS, 2019) and the Local Data Bank. In empirical research, statistical data from five areas were used: population and labour market, natural environment, recreation and culture, infrastructure, economy. Table 1 shows the set of initial characteristics by areas.

Table 1. Set of initial characteristics by areas in years 2004 and 2017

\begin{tabular}{|c|c|c|}
\hline Area & Symbols & Characteristic \\
\hline \multirow{10}{*}{$\begin{array}{l}\text { Population } \\
\text { and } \\
\text { labour market }\end{array}$} & $\mathrm{X} 1$ & Number of people per $1 \mathrm{~km}^{2}$ \\
\hline & $\mathrm{x} 2$ & Infant deaths per 1000 live births \\
\hline & $\mathrm{X} 3$ & Natural increase per 1000 people \\
\hline & $\mathrm{X} 4$ & Non-working population per 100 working age people \\
\hline & $\mathrm{X} 5$ & Post-working population per 100 pre-working age people \\
\hline & $\mathrm{x} 6$ & Post-working population per 100 working age people \\
\hline & $\mathrm{X} 7$ & Share of total employed in the population (in\%) \\
\hline & $\mathrm{x} 8$ & Registered unemployment rate (in\%) \\
\hline & X9 & Share of unemployed for more than 1 year in total number of unemployed (in\%) \\
\hline & $\mathrm{X} 10$ & Share of unemployed aged 24 and less in total number of unemployed (in\%) \\
\hline \multirow{6}{*}{$\begin{array}{l}\text { Natural } \\
\text { environment }\end{array}$} & $\mathrm{X} 11$ & Water consumption for the needs of the national economy and population in dam ${ }^{3}$ per $1 \mathrm{~km}^{2}$ \\
\hline & $\mathrm{X} 12$ & Percentage of the population connected to wastewater treatment plants (in\%) \\
\hline & $\mathrm{X} 13$ & Wastewater treated in $\mathrm{dm}^{3}$ per $100 \mathrm{~km}^{2}$ \\
\hline & $\mathrm{X} 14$ & Gaseous emissions in t per $100 \mathrm{~km}^{2}$ \\
\hline & $\mathrm{X} 15$ & Forest area in ha per $\mathrm{km}^{2}$ \\
\hline & $\mathrm{X} 16$ & Share of protected areas in the total area (in\%) \\
\hline \multirow{8}{*}{$\begin{array}{l}\text { Recreation } \\
\text { and culture }\end{array}$} & $\mathrm{X} 17$ & Defert's indicator $^{1}$ \\
\hline & $\mathrm{X} 18$ & Schneider's indicator ${ }^{2}$ \\
\hline & $\mathrm{X} 19$ & Charvat's indicator $^{3}$ \\
\hline & X20 & Tourist density indicator ${ }^{4}$ \\
\hline & $\mathrm{X} 21$ & Accommodation density index ${ }^{5}$ \\
\hline & X22 & Average length of stay \\
\hline & $\mathrm{x} 23$ & Book collection in volumes per 1000 population \\
\hline & X24 & Population per 1 library \\
\hline
\end{tabular}


Oesterreich M., Perzyńska J., Barej-Kaczmarek E., APPLICATION OF THE TOPSIS PROCEDURE FOR EVALUATION OF SOCIO-ECONOMIC DEVELOPMENT OF THE WEST POMERANIAN VOIVODESHIP DISTRICTS IN YEARS 2004-2017, Zeszyty Naukowe Uniwersytetu Przyrodniczo-Humanistycznego w Siedlcach Nr 122, Seria: Administracja i Zarządzanie (49) 2019

\begin{tabular}{|c|c|c|}
\hline \multirow{14}{*}{ Infrastructure } & $\mathrm{X} 25$ & Dwellings per 1000 population \\
\hline & X26 & Completed dwellings per 1,000 population \\
\hline & $\mathrm{X} 27$ & Water supply network in $\mathrm{km}$ per $100 \mathrm{~km}^{2}$ \\
\hline & $\mathrm{X} 28$ & Wastewater network in km per $100 \mathrm{~km}^{2}$ \\
\hline & X29 & Beds in hospitals per 10,000 people \\
\hline & X30 & Population per 1 healthcare entity \\
\hline & X31 & Population per 1 pharmacy \\
\hline & X32 & Districts roads with a hard surface in $\mathrm{km}$ per $100 \mathrm{~km}^{2}$ \\
\hline & X33 & Number of boiler rooms on $100 \mathrm{~km}^{2}$ \\
\hline & X34 & Length of transmission and distribution heating network in km per $100 \mathrm{~km}^{2}$ \\
\hline & X35 & $\begin{array}{l}\text { Length of connections of the transmission and distribution heating network to buildings in } \mathrm{km} \text { per } \\
100 \mathrm{~km}^{2}\end{array}$ \\
\hline & X36 & The percentage of people using the plumbing installation (in\%) \\
\hline & X37 & The percentage of people using wastewater installations (in\%) \\
\hline & X38 & Percentage of population using the gas installation (in\%) \\
\hline \multirow{7}{*}{ Economy } & X39 & Housing benefits in PLN per capita \\
\hline & X40 & Investment in enterprises in PLN per capita \\
\hline & $\mathrm{X} 41$ & Gross value of fixed assets in PLN per capita \\
\hline & X42 & Entities of the national economy per 10,000 population \\
\hline & X43 & Average monthly gross salary (in PLN) \\
\hline & X44 & Revenue of districts budgets in PLN per capita \\
\hline & X45 & Expenditure of districts budgets in PLN per capita \\
\hline
\end{tabular}

${ }^{1}$ number of beds per 100 permanent residents; ${ }^{2}$ tourists accommodated in tourist accommodation establishments per 100 resident; ${ }^{3}$ overnight stays in tourist establishments per 100 residents; ${ }^{4}$ tourists accommodated in tourist accommodation

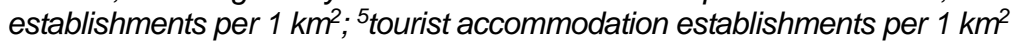

Source: own study

Stage 2. Reduction of the initial set of characteristics

The initial set of 45 characteristics was reduced to the set with high level of diagnostic value (Roszkowska et al., 2017). For this purpose, a twostep procedure of selecting features for the study was used, which guaranteed high variability of values and their low correlation (Grabiński, 1992, Tarka, 2010).

\section{Step 2.1. Elimination of features characterized by low variability}

Characteristics were eliminated separately for 2004 and 2017. For this purpose, the classical coefficient of variation was used (Anderson et al., 2011, p. 99), where minimum limit value was set at $10 \%$.

\section{Step 2.2. Elimination of highly correlated features}

To eliminate characteristics that were highly correlated with other ones, the parametric Hellwig selection method was used (Nowak, 1990, pp. 28-33). The critical value of the absolute value of Pearson's linear correlation coefficient was set arbitrarily at 0.7 .

As a result of conducted operations, the set of initial features decreased to 17 elements for the year 2004 and to 18 elements for the year 2017. The final diagnostic features were the common part of the reduced sets of characteristics from 2004 and 2017. Symbols of 13 final characteristics are:
$X 2, X 12, X 15, X 16, X 23, X 29, X 30, X 31, X 35, X 38$, $\mathrm{X} 39, \mathrm{X} 40, \mathrm{X} 42$.

Next, features that are stimulants and destimulants (for which increase of values has a positive or negative effect on the level of the analysed phenomenon) were identified. The final diagnostic characteristics were presented in the form of two matrices:

$X_{\mathrm{t}}=\left[x_{i k t} \mathrm{t}\right]$

where:

$i$ - district number $(i=1,2, \ldots, 21)$

$k$-characteristic number $(k=1,2, \ldots, 13)$

$x_{i k_{i}, t}$ - value of $k$-th characteristic for $i$-th district in year $t$ $(t=2004,2017)$.

Stage 3. Determination of synthetic measures of development and construction of districts rankings

A taxonomic measure of districts development was determined using the TOPSIS (Technique for Order Preference by Similarity to an Ideal Solution) method presented firstly by Hwang and Yoon in 1981 (Manoj, 2013; Parida and Sahoo, 2013). The TOPSIS procedure introduces two reference points - pattern and anti-pattern of values for each diagnostic feature. The pattern specifies the coordinates of an ideal object, the anti-pattern negative ideal object. The basic principle of this technique is that the preferred object (in the 
conducted research - district) should have the shortest distance from the pattern (Positive Ideal Solution) and the farthest distance from the antipattern (Negative Ideal Solution). In the research, the TOPSIS procedure was modified, it proceeded in eight steps.

\section{Step 3.1. Weights selection}

Weights were selected that met the condition:

$$
\sum_{k=1}^{13} w_{k}=1
$$

where: $w_{k}-$ weight of $k$-th diagnostic characteristic.
In the simplest case, the weights can be the same. In the study, it was decided to assign individual weights for each characteristics to exclude the possibility of the influence of a different number of final diagnostic characteristics in categories on the value of the calculated synthetic measure. The weights were selected in such a way that their sum for each category was the same and equals 0,2 (see Walesiak and Obrębalski, 2017). Table 2 shows values of weights by areas.

Table 2. Individual weights of diagnostic characteristics by areas

\begin{tabular}{lccccc}
\hline & $\begin{array}{c}\text { Population and } \\
\text { labour market }\end{array}$ & $\begin{array}{c}\text { Natural } \\
\text { environment }\end{array}$ & $\begin{array}{c}\text { Recreation } \\
\text { and culture }\end{array}$ & Infrastructure & Economy \\
\hline Number of features & 1 & 3 & 1 & 5 & 3 \\
Weight & $1 / 5$ & $1 / 15$ & $1 / 5$ & $1 / 25$ & $1 / 15$ \\
\hline
\end{tabular}

Based on selected weights, weighted matrices were determined:

$V_{t}=\left[v_{i k, t}\right]$

with elements equal to:

$v_{i k, t}=w_{k} x_{i k t}$

where:

$v_{i k_{z} t}-$ weighted value of $k$-th diagnostic characteristic for $i$-th district in year $t$.

\section{Step 3.2. Standardization of characteristics}

To ensure data comparability, the values of diagnostic characteristics were standardized (so that their arithmetic mean was 0 and the standard deviation equals 1) based on the formula:

$\nabla_{i k, t}=\frac{v_{i k, t}-\bar{v}_{k, t}}{S\left(v_{k, t}\right)}$

where:

$\bar{v}_{k, t}$-arithmetic mean of $k$-th characteristic in year $t$, $S\left(v_{k_{t} t}\right)$ - standard deviation of $k$-th characteristic in year $t$.

\section{Step 3.3. Determination of Positive and Negative} Ideal Solutions

The coordinates of the common pattern (Positive Ideal Solution) and anti-pattern (Negative Ideal Solution) for each diagnostic characteristics were determined on the basis of the following formulas respectively: $z_{k}^{+}=\left\{\begin{array}{l}\max _{i, t} z_{i k, t} \quad \text { dla stymulanty } \\ \min _{i, t} z_{i k_{n}, t} \text { dla destymulanty }\end{array}\right.$

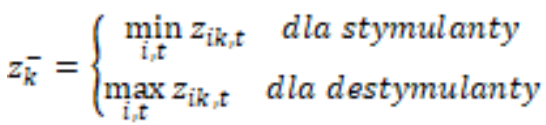

where:

$z_{k}^{+}-k$-th coordinate of Positive Ideal Solution,

$z_{k}^{-}-k$-th coordinate of Negative Ideal Solution.

Step 3.4. Determination of distances between districts and both Ideal Solutions

Euclidean distances between each district and each Ideal Solution (Positive and Negative) were determined for both years:

$$
\begin{aligned}
& d_{i, t}^{+}=\sqrt{\sum_{k=1}^{12}\left(z_{i k, t}-z_{k}^{+}\right)^{2}} \\
& d_{i, t}^{-}=\sqrt{\sum_{k=1}^{13}\left(z_{i k, t}-z_{k}^{-}\right)^{2}}
\end{aligned}
$$

where:

$d_{i, t}^{+}$- Euclidean distance between $i$-th district and Positive Ideal Solution in year $t$,

$d_{i, t}^{-}$- Euclidean distance between $i$-th district and Negative Ideal Solution in year $t$. 
Oesterreich M., Perzyńska J., Barej-Kaczmarek E., APPLICATION OF THE TOPSIS PROCEDURE FOR EVALUATION OF SOCIO-ECONOMIC DEVELOPMENT OF THE WEST POMERANIAN VOIVODESHIP DISTRICTS IN YEARS 2004-2017, Zeszyty Naukowe Uniwersytetu Przyrodniczo-Humanistycznego w Siedlcach Nr 122, Seria: Administracja i Zarządzanie (49) 2019

Step 3.5. Determination of synthetic measures of development

The values of the taxonomic measure of development was calculated for each district in both years using the formula:

$$
T M D_{i, t}=\frac{d_{i, t}^{-}}{d_{i, t}^{-}-d_{i, t}^{+}}
$$

where:

$T M D_{i, t^{-}}$taxonomic measure of development of $i$-th district in year $t$.

\section{Step 3.6. Construction of districts rankings}

with respect to value of synthetic measure of development

Based on the calculated values of the taxonomic measure of development, rankings of districts for each year were created, sorting them according to the non-decreasing value of $T M D_{i, t}$.

\section{Step 3.7. Determination of synthetic measures of} pace development

A taxonomic measure of development pace of the districts was determined by modifying the procedure proposed by Hydzik (Hydzik, 2012). The final diagnostic characteristics are an intersection of two reduced sets of features from 2004 and 2017, so they constitute a uniform set of characteristics on the basis of which a taxonomic measure of pace development can be determined as a relative increase:

$$
T M D_{i, 2017 / 2004}=\frac{T M D_{i, 2017}-T M D_{i, 2004}}{T M D_{i, 2004}}
$$

\section{Step 3.8. Construction of districts rankings with respect to value of synthetic measure of pace development}

As in the case of synthetic measure $T M D_{i, t}$, districts rankings were created, sorting them by the non-decreasing value of the measure given by formula (11).

\section{Stage 4. Creation of typological groups of districts}

Districts were classified into typological groups differing in the level of development in 2004, in 2017 and the pace of development. The classification was based on the values of parameters $T M D_{i, 2004}$, $T M D_{i, 2017}$ and $T M D_{i, 2017 / 2004}$ (Bąk i Szczecińska, 2016, p. 29). Four groups of districts (with numbers 1-4) characterized by a similar level of development (high, high middle, low middle, low) were identified for both years using formula respectively:

$$
\begin{gathered}
T M D_{i, t} \geq \overline{T M D_{t}}+S\left(T M D_{t}\right) \\
\overline{T M D_{t}} \leq T M D_{i, t}<\overline{T M D_{t}}+S\left(T M D_{t}\right) \\
\overline{T M D_{t}}-S\left(T M D_{t}\right) \leq T M D_{i, t}<\overline{T M D_{t}} \\
T M D_{i, t}<\overline{T M D_{t}}-S\left(T M D_{t}\right)
\end{gathered}
$$

where:

$\overline{T M D_{t}}$ - arithmetic mean of taxonomic measure of districts development in year $t$,

$S\left(T M D_{t}\right)$ - standard deviation of taxonomic measure of districts development in year $t$,

The classification of districts into four typological groups with a similar pace of development was analogous.

\section{Results and discussion}

Based on the reduced final set of diagnostic characteristics, in accordance with modified TOPSIS procedure, taxonomic measures of level and pace development were determined using formulas (10) and (11). Based on values of synthetic measures for both years, typological groups of districts with a similar level and pace of development were identified. Table 3 shows obtained values of synthetic measures and ranks assigned to districts, as well as absolute increments of their values, group numbers assigned to districts.

The average value of taxonomic measure of districts development in 2004 year was 0,492, its variation coefficient $17,80 \%$, and the range 0,352 . Out of 21 analysed districts, 10 reached higher values of synthetic measure than average.

The highest values of taxonomic measure in 2004 were recorded for the following districts: Kamieński $(0,680)$, Choszczeński $(0,630)$ and Świnoujście city $(0,622)$. These districts were classified in group 1 - with the highest level of development. The lowest values of synthetic measure (and at the same time the lowest level of development, meaning they belonged to group 4) were recorded for districts: Koszaliński $(0,378)$, Białogardzki $(0,367)$ and Wałecki $(0,329)$. Figure 1 shows the spatial distribution of values of taxonomic measure in 2004. 
Oesterreich M., Perzyńska J., Barej-Kaczmarek E., APPLICATION OF THE TOPSIS PROCEDURE FOR EVALUATION OF SOCIO-ECONOMIC DEVELOPMENT OF THE WEST POMERANIAN VOIVODESHIP DISTRICTS IN YEARS 2004-2017, Zeszyty Naukowe Uniwersytetu Przyrodniczo-Humanistycznego w Siedlcach Nr 122, Seria: Administracja i Zarządzanie (49) 2019

Table 3. Synthetic measures, ranks and absolute increments of their values, classification into groups by districts in the years 2004 and 2017

\begin{tabular}{|c|c|c|c|c|c|c|c|c|c|c|c|}
\hline & \multirow{2}{*}{ Districts } & \multicolumn{3}{|c|}{2004} & \multicolumn{3}{|c|}{2017} & \multicolumn{4}{|c|}{ 2004->2017 } \\
\hline & & $T M D_{i, 2004}$ & rank & group & $T M D_{i, 2017}$ & rank & group & change of ranks & $T M D_{1,2017 / 2004}$ & rank & group \\
\hline 1 & Białogardzki & 0,367 & 20 & 4 & 0,547 & 6 & 2 & -14 & 0,489 & 1 & 1 \\
\hline 2 & Choszczeński & 0,630 & 2 & 1 & 0,607 & 2 & 1 & 0 & $-0,037$ & 11 & 3 \\
\hline 3 & Drawski & 0,529 & 8 & 2 & 0,487 & 13 & 3 & 5 & $-0,078$ & 15 & 3 \\
\hline 4 & Goleniowski & 0,462 & 12 & 3 & 0,357 & 19 & 4 & 7 & $-0,228$ & 20 & 4 \\
\hline 5 & Gryficki & 0,430 & 18 & 3 & 0,342 & 21 & 4 & 3 & $-0,204$ & 19 & 4 \\
\hline 6 & Gryfiński & 0,520 & 9 & 2 & 0,560 & 4 & 2 & -5 & 0,078 & 6 & 2 \\
\hline 7 & Kamieński & 0,680 & 1 & 1 & 0,702 & 1 & 1 & 0 & 0,031 & 8 & 2 \\
\hline 8 & Kołobrzeski & 0,562 & 4 & 2 & 0,559 & 5 & 2 & 1 & $-0,006$ & 10 & 3 \\
\hline 9 & Koszaliński & 0,378 & 19 & 4 & 0,476 & 14 & 3 & -5 & 0,261 & 3 & 1 \\
\hline 10 & Myśliborski & 0,540 & 7 & 2 & 0,495 & 11 & 2 & 4 & $-0,084$ & 16 & 3 \\
\hline 11 & Policki & 0,467 & 11 & 3 & 0,445 & 17 & 3 & 6 & $-0,047$ & 12 & 3 \\
\hline 12 & Pyrzycki & 0,559 & 5 & 2 & 0,490 & 12 & 3 & 7 & $-0,124$ & 18 & 3 \\
\hline 13 & Sławieński & 0,450 & 14 & 3 & 0,451 & 16 & 3 & 2 & 0,002 & 9 & 3 \\
\hline 14 & Stargardzki & 0,431 & 17 & 3 & 0,402 & 18 & 4 & 1 & $-0,068$ & 14 & 3 \\
\hline 15 & Szczecinecki & 0,446 & 15 & 3 & 0,508 & 10 & 2 & -5 & 0,141 & 5 & 2 \\
\hline 16 & Świdwiński & 0,453 & 13 & 3 & 0,346 & 20 & 4 & 7 & $-0,238$ & 21 & 4 \\
\hline 17 & Wałecki & 0,329 & 21 & 4 & 0,459 & 15 & 3 & -6 & 0,399 & 2 & 1 \\
\hline 18 & Łobeski & 0,502 & 10 & 2 & 0,536 & 7 & 2 & -3 & 0,068 & 7 & 2 \\
\hline 19 & Koszalin & 0,548 & 6 & 2 & 0,515 & 9 & 2 & 3 & $-0,062$ & 13 & 3 \\
\hline 20 & Szczecin & 0,436 & 16 & 3 & 0,525 & 8 & 2 & -8 & 0,204 & 4 & 2 \\
\hline 21 & Świnoujście & 0,622 & 3 & 1 & 0,563 & 3 & 2 & 0 & $-0,095$ & 17 & 3 \\
\hline
\end{tabular}

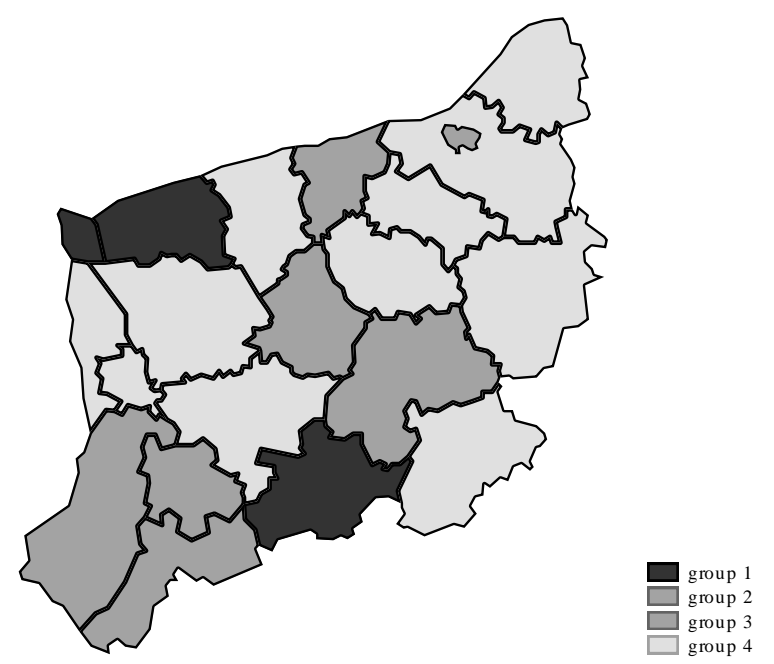

Figure 1. Spatial distribution of values of taxonomic measure of development in the year 2004 by the West Pomeranian Voivodeship districts Source: own study

The average value of synthetic measure of development in 2017 was 0,494 , variation coefficient $17,32 \%$, range 0,360 . Out of all districts, 11 reached higher values of measure than average.
In 2017, the highest values of synthetic measure, similarly to 2004, were recorded for districts: Kamieński $(0,702)$, Choszczeński $(0,607)$ and Świnoujście city $(0,563)$. The first two districts were again classified into group 1 with the highest level of development, but the third mentioned district belonged to group 2 with a high middle level. The lowest values of synthetic measure were in districts: Goleniowski $(0,357)$, Świdwiński $(0,346)$ and Gryficki $(0,342)$. In 2017, these districts were classified to group 4 with the lowest level of development, while in 2004 they were belonging to group 3 and their level of development was low middle.

It should also be noted that districts that in 2004 belonged to group 4 (low level), in 2017 reached a higher level - Koszaliński and Wałecki belonged to group 3 (low middle level), and Białogardzki to group 2 (high middle level).

Figure 2 shows the spatial distribution of values of taxonomic measure in 2017 . The analysis of ranks assigned to districts, depending on the value of synthetic measure of development in the 
years 2004 and 2017, shows that the largest promotion equals 14 positions, was recorded for the Białogardzki district (from 20th to 6th place). The largest decrease in the ranking (7 places), was recorded for three districts: Pyrzycki (from 5th to 12th place), Goleniowski (from 12th to 19th place) and Świdwiński (from 13th to 20th place).

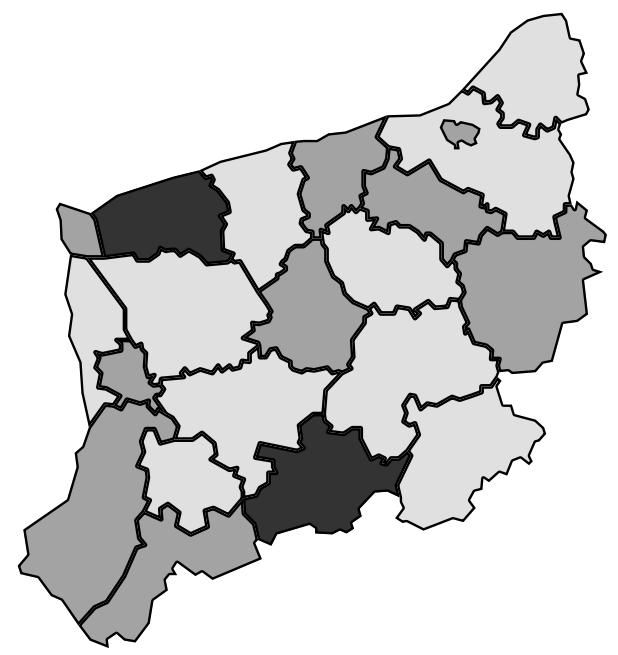

group 1 group 2 group 3

Figure 2. Spatial distribution of values of taxonomic measure of development in the year 2017 by the West Pomeranian Voivodship districts Source: own study

Among the analysed districts, an increase in the value of taxonomic measure of development was noted for 9 districts, and a decrease for 12 of them. The highest absolute and relative increases of values of synthetic measure between 2004 and 2017 were recorded for the Białogardzki district respectively: 0,180 i $0,489 \%$. The largest decrease in the value of the synthetic measure $(0,108$ i.e. 23.8\%) was recorded for the Świdwiński district. Figure 3 shows the spatial distribution of values of relative increments of taxonomic measures between 2004 and 2017.

The smallest relative increase in the value of synthetic measure of development pace was recorded for the Świdwiński, Goleniowski and Gryficki districts, which belonged to group 4 with a low pace of development. In 2004 these districts were characterized by a low middle level of development.

Analyses of the values of diagnostic features for the Białogardzki and Świdwiński districts show that the features: $X 23, X 30$ and $X 31$ have the highest impact on the pace of change of socioeconomic development in the studied period. In the areas represented by these features, the situation clearly deteriorated in relation to 2004 . In the case of the białogardzki district, the deterioration was clearly lower than for the Świdwiński district.

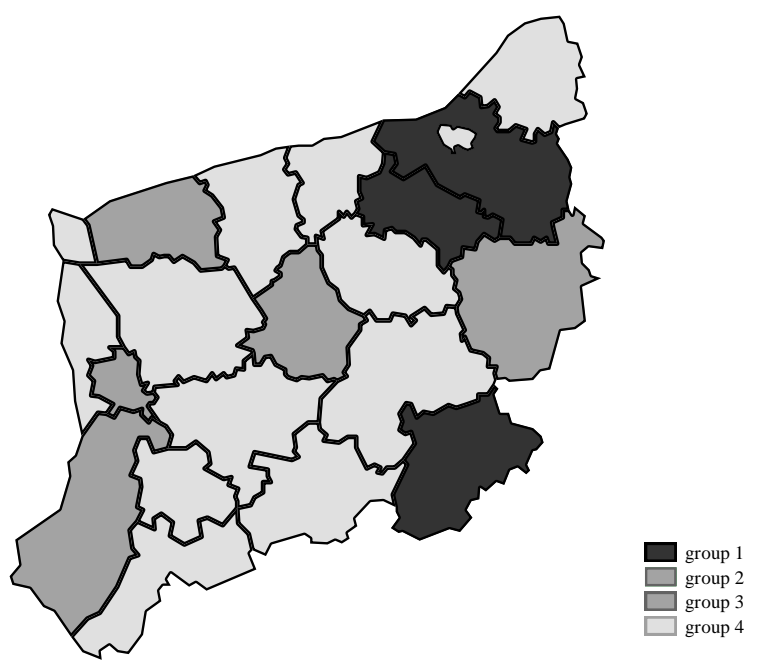

Figure 3. Spatial distribution of values of relative increments of taxonomic measures between 2004 and 2017 by the West Pomeranian Voivodship districts Source: own study

Table 4 shows the values of the Kendall's rank correlation coefficient (Abdi, 2007, Ostasiewicz, 1998, p. 63) between the districts positions for the years 2004 and 2017 determined on the basis of the values of taxonomic measure of development and taxonomic measure of pace development

Table 4. Estimates of Kendall's rank correlation coefficient

\begin{tabular}{lccc}
\hline & 2004 & 2017 & $2004->2017$ \\
\hline 2004 & 1,000 & 0,448 & $-0,267$ \\
2017 & 0,448 & 1,000 & 0,286 \\
$2004->2017$ & $-0,267$ & 0,286 & 1,000 \\
\hline
\end{tabular}

The low value of the Kendall's rank correlation coefficient between the ranks calculated on the basis of synthetic measures for 2004 and 2017, equals to 0.448 , indicates a weak relationship between the level of socio-economic development of the surveyed districts in these years.

A negative sign of the correlation coefficient between ranks dependent on the level of development in 2004 and its pace in 2004-2017 suggests that districts with a low level of development in 2004 developed faster, which confirms earlier conclusions. 


\section{Conclusions}

Poland's accession to the European Union accelerated the socio-economic development of not only the country as a whole, but above all its regions. In the case of the West Pomeranian Voivodship, this development is visible through the prism of changes taking place in its districts.

The application of taxonomic methods allowed evaluating the level and pace of development of the West Pomeranian Voivodship districts since accession to the EU. The multidimensionality of development is a challenge when specifying characteristics to empirical research, therefore the large initial set of features was reduced to provide them with the highest diagnostic value. The final diagnostic characteristics were selected as an intersection of the reduced sets from the years 2004 and 2017, making them a uniform set on the basis of which it was possible to compare the values of synthetic taxonomic measures (determined in the modified TOPSIS procedure) from both years. Synthetic conclusions from empirical research are as follows:

1. An analysis of the average values of taxonomic development measures in the years 2004 and 2017 indicates an increase of the level of socio-economic development of the West Pomeranian Voivodship districts.

2. Values of variation coefficients of taxonomic development measures greater than 17\% indicate the existence of a large diversity of districts with respect to the level of socioeconomic development in 2004 and 2017.

3. The range of values of taxonomic development measure increased in 2017 compared to 2004 , means that the diversification of districts development has deepened.

4. The highest level of socio-economic development in both years was characteristic for the Kamieński district. The lowest level of development in 2004 was observed in the Wałecki district and in 2017 in the Gryficki district.

5. The vast majority of districts have changed their position in the ranking relative to 2004, and the assessment of the similarity of the districts order over time is low.

6. The highest pace of changes in the level of socio-economic development between 2004 and 2017 was recorded for the Białogardzki district, while the lowest for the Świdwiński district and was connected with changes of values of features from two areas: recreation and culture, infrastructure.

7. The comparison of taxonomic measures of level and pace development shows that level increased faster in districts characterized by a low development level in 2004.

\section{References}

Abdi, H. (2007). The Kendall Rank Correlation Coefficient, https://personal.utdallas.edu/ herve/ Abdi-KendallCorrelation2007-pretty.pdf (17.10.2019).

Anderson, D.R., Sweeney, D.J, Williams, T.A. (2011). Statistics for business and economics., South-Western: Cengage learning.

Bak, I., Szczecińska, B. (2016). Przestrzenne zróżnicowanie województw Polski pod względem sytuacji społeczno-gospodarczej. Prace Naukowe Uniwersytetu Ekonomicznego we Wrocławiu, 439, 23-34. doil: 10.15611/pn.2016.439.02.

Brol, R. (1998). Zarządzanie rozwojem lokalnym studium przypadków. Wrocław: Akademia Ekonomiczna.

Cyburt, A., Hołownia, P., Kuźmicki, M. (2016). Cooperation between local authorities and nongovernmental organisations for the benefit of local development. Economic and regional studies, 9(3), p. 47-58. Retrieved from: http://www.ers.edu.pl/wspolpraca-jednosteksamorzadu-terytorialnego-i-organizacjipozarzadowych-na-rzecz,92957,0,2.html (22.10.2019).

Dasi J.F. (2014). Identity and Territorial Character: Re-Interpreting Local-Spatial Development. València: Publicacions de la Universitat de València.

European Commission (1999). European Spatial Development Perspective. Towards a more competitive and sustainable Europe of diverse regions. Retrieved from: https://ec.europa.eu/ regional_policy/sources/docoffic/official/reports/ pdf/sum_en.pdf (24.10.2019).

European Commission (2014). Community-led Local Development. Retrieved from: https://ec.europa.eu/regional_policy/sources/do cgener/informat/2014/community_en.pdf (24.10.2019).

European Commission (2019). Policy Coherence for Development. 2019 EU Report. Retrieved from: https://ec.europa.eu/europeaid/sites/ devco/files/eu-report-pcd-2019_en.pdf (17.10.2019).

Gorynia, M., Łaźniewska, E. (ed.) (2010). Kompedium wiedzy o konkurencyjności. Warszawa: PWN. 
Oesterreich M., Perzyńska J., Barej-Kaczmarek E., APPLICATION OF THE TOPSIS PROCEDURE FOR EVALUATION OF SOCIO-ECONOMIC DEVELOPMENT OF THE WEST POMERANIAN VOIVODESHIP DISTRICTS IN YEARS 2004-2017, Zeszyty Naukowe Uniwersytetu Przyrodniczo-Humanistycznego w Siedlcach Nr 122, Seria: Administracja i Zarządzanie (49) 2019

Gorzelak, G., Smętkowski, M. (2019). Rozwój regionalny, Polityka regionalna. Forum Obywatelskiego Rozwoju, Retrieved from: https://for.org.pl/pl/publikacje/raporty-for/raportfor-rozwoj-regionalny-polityka-regionalna (10.11.2019).

Grabiński, T. (1992). Metody taksonometrii. Kraków: Akademia Ekonomiczna w Krakowie.

Grycuk, A., Rusel, P. (2017). Członkostwo w Unii Europejskiej a rozwój gospodarczy Polski. Wybrane zagadnienia. INFOS, 12(235), Retrieved from: https://www.google.com/ url? sa $=$ t\&rct=j\&q=\&esrc $=$ s $\&$ source $=$ web $\& c d=5$ $\&$ cad $=$ rja\&uact $=8 \& v e d=2 a h U K E w i C-c X g 5 u b l$ AhUHaFAKHYpCBSwQFjAEegQIBhAC\&url=ht tp\%3A\%2F\%2Forka.sejm.gov.pl\%2FWydBAS. nsf\%2F0\%2F8974D205A147BE5AC12581C20 036884D\%2F\%24file\%2FInfos_235.pdf\&usg=A OvVaw07tk8B2wSelYdB3WUVAgSA (10.11.2019).

GUS (2019). Zachodniopomorskie voivodship. Subregions, powiats, gminas. Retrived from: https://szczecin.stat.gov.pl/publikacje-i-foldery/ roczniki-statystyczne/wojewodztwo-zachodniopomorskie-2018-podregiony-powiaty-gminy, 7,18.html (24.10.2019).

Hydzik, P. (2012). Zastosowanie metod taksonomicznych do oceny poziomu rozwoju społeczno-ekonomicznego powiatów województwa podkarpackiego. Zeszyty Naukowe Politechniki Rzeszowskiej, 286(19), 17-32.

Łaźniewska, E., Gorynia, M. (Ed.) (2012). Konkurencyjność regionalna. Koncepcje strategie - przykłady. Warszawa: PWN.

Manoj, S. (2013). Multi Attribute Decision Making Techniques. International Journal of Research in Management, Science \& Technology,1(1), 49-51.

Nowak E. (1990) Metody taksonomiczne w klasyfikacji obiektów społeczno-gospodarczych. Warszawa: PWE, s. 85-95.

OECD (2018). Reshaping Decentralised Development Co-operation. The Key Role of Cities and Regions for the 2030 Agenda. Retrieved from: https://www.oecd.org/cfe/ reshaping-decentralised-development-cooperation-9789264302914-en.htm (22.10.2019).

Ostasiewicz W. (Ed.) (1998) Statystyczne metody analizy danych. Wydawnictwo Akademii Ekonomicznej im. Oskara Langego we Wrocławiu, Wrocław.

Parida, P., Sahoo, S. (2013). Multiple Atribute Decision Making Approach by TOPSIS technique. International Journal of Engineering Research \& Technology, 2(11), 907-912.
Parysek, J. (1995). Rozwój lokalny zagospodarowanie przestrzenne i nisze atrakcyjności gospodarczej. Warszawa: PWN.

Parysek, J. (2001). Podstawy gospodarki lokalnej. Poznań: Wydawnictwo UAM.

PLATFORMA (2012). Decentralised development cooperation - European perspectives. Retrieved from: https://www.ccre.org/docs/Platforma European_perspectives_EN.pdf (24.10.2019).

Roszkowska, E., Filipowicz-Chomko, M., Wachowicz T. (2017). Wykorzystanie metody TOPSIS do oceny zróżnicowania rozwoju województw Polski w latach 2010-2014 w kontekście kształtowania się ładu instytucjonalnego. Prace Naukowe Uniwersytetu Ekonomicznego we Wrocławiu, 469(29), 149-158.

Sienkiewicz, M.W., (2015). The impact of crosssectoral partnerships on local development on the example of activity lags in Lublin province. Zarządzanie Publiczne, 4 (32), p. 330-350, DOI:10.4467/20843968ZP.15.021.4767.

SPERI (2018) UK regions and European structural and investment funds. Sheffield Political Economy Research Institute. Retrieved from: http://speri.dept.shef.ac.uk/wpcontent/uploads/2018/11/Brief24-UK-regionsand-European-structural-and-investmentfunds.pdf (15.10.2019).

Szewczuk, A., Kogut-Jaworska, M., Zioło, M. (2011). Rozwój lokalny i regionalny. Teoria i praktyka. Warszawa: Wyd. C.H. Beck.

Tarka, D. (2011). Własności cech diagnostycznych w badaniach typu taksonomicznego. Ekonomia i zarządzanie, 2(4), 194-205.

UN (2015) Transforming our world: the 2030 Agenda for Sustainable Development, https://sustainabledevelopment.un.org/post201 5/transformingourworld (24.10.2019).

Walesiak, M., Obrębalski, M. (2017). Spójność społeczna województwa dolnośląskiego w latach 2005-2015 - pomiar i ocena zmian. Przegląd Statystyczny, LXIV(4), 437-455.

Wiatrak, A. P. (2018). Determinants of local development strategies. Acta Scientiarum Polonorum, 17(1) p. 113-120, doi: 10.22630/ ASPE.2018.17.1.13.

Winiarski, B., Patrzałek, L. (Ed.) (1994). Promowanie rozwoju lokalnego i regionalnego. Warszawa: Wydawnictwo Samorządowe Fundacji Rozwoju Demokracji Lokalnej. 